TABLE 1

\begin{tabular}{|c|c|c|c|c|c|}
\hline \multirow[t]{2}{*}{ Sample No. } & \multirow[t]{2}{*}{$\begin{array}{c}\text { Intensity } \\
\text { (e.m.u. } / \mathrm{gm} . \times 10^{5} \text { ) }\end{array}$} & \multicolumn{2}{|c|}{ Direction } & \multicolumn{2}{|c|}{$\begin{array}{l}\text { Corrected } \\
\text { Direction }\end{array}$} \\
\hline & & Decli. & Incli. & Decli. & Incl \\
\hline $\begin{array}{l}A 1 \\
A 2 \\
A 3 \\
A 4\end{array}$ & $\begin{array}{r}.7 \cdot 2 \\
5 \cdot 8 \\
7 \cdot 6 \\
7 \cdot 4\end{array}$ & $\begin{array}{ll}\text { N. } 33^{\circ} \mathrm{E} . \\
\text { N.20 } & \mathbf{E} . \\
\text { N.16 } & \text { W. } \\
\text { N. } 8 & \text { W. }\end{array}$ & $\begin{array}{l}78^{\circ} \\
40 \\
50 \\
60\end{array}$ & $\begin{array}{l}\text { N.73 }{ }^{\circ} \mathrm{E} . \\
\text { N.41 } \\
\text { E. } \\
\text { N.31 E. } \\
\text { N.44 } \\
\text { E. }\end{array}$ & $\begin{array}{c}31^{\circ} \\
8 \\
30 \\
30\end{array}$ \\
\hline
\end{tabular}
Pole position derived from mean values of the above four.
lat. $=18^{\circ} \mathrm{N}$, long. $=137^{\circ} .5 \mathrm{~W}$. Corrected, lat. $=2^{\circ} .5 \mathrm{~S}$, lat. $=96^{\circ} \mathrm{W}$.

\begin{tabular}{|c|c|c|c|c|}
\hline$A 1$ & $12 \cdot 2$ & N. $34^{\circ} \mathrm{W}$. & $69^{\circ}$ & N. $52^{\circ} \mathrm{E}$ \\
\hline$A_{2}$ & 18.6 & N.10 W. & 68 & N.52 $\mathrm{E}$ \\
\hline$A 3$ & 3.0 & N.37 W. & 61 & N.36 $\mathrm{E}$ \\
\hline$A 4$ & $14 \cdot 4$ & N.49 W. & 40 & N. $2 \mathrm{E}$ \\
\hline$A 5$ & $20 \cdot 4$ & N. $9 \mathrm{~W}$. & 41 & $\mathrm{~N} .25 \mathrm{~F}$ \\
\hline$A 6$ & $22 \cdot 2$ & N.42 W. & 58 & N.38 E \\
\hline$A 7$ & $13 \cdot 0$ & $\mathrm{~N} .29 \mathrm{~W}$. & 58 & $\mathrm{~N} .33 \mathrm{E}$ \\
\hline$A 8$ & $21 \cdot 2$ & $\mathrm{~N} .33 \mathrm{~W}$ & 66 & $\mathrm{~N}, 46 \mathrm{E}$ \\
\hline
\end{tabular}
Pole position derived from mean values of the above eight.
lat. $=20^{\circ} .5 \mathrm{~N}$, long. $=166^{\circ} .5 \mathrm{~W}$. Corrected. lat. $=3^{\circ} .5 \mathrm{~N}$, long. $=107^{\circ} .5 \mathrm{~W}$.

\begin{tabular}{|c|c|c|c|c|c|}
\hline$C 1$ & $5 \cdot 8$ & $\mathrm{~N} .27^{\circ} \mathrm{W}$. & $39^{\circ}$ & N.10 $0^{\circ} \mathrm{E}$. & $27^{\circ}$ \\
\hline$C 2$ & 6.8 & $\mathrm{~N} .29 \mathrm{~W}$. & 42 & N.14 E. & 30 \\
\hline C3 & $9 \cdot 2$ & N.35 W. & 64 & N.39 E. & 42 \\
\hline$C 4$ & $8 \cdot 6$ & N.50 W. & 70 & N.47 E. & 48 \\
\hline$C 5$ & $33 \cdot 6$ & N.35 W. & 62 & N.45 E. & 43 \\
\hline$C 6$ & 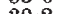 & $\mathbf{N}$ & 50 & N.29 $\mathrm{E}$ & 40 \\
\hline
\end{tabular}
Pole position derived from mean values of the above six.
lat. $=16^{\circ} \mathrm{N}$, long. $=168^{\circ} \mathrm{W}$. Corrected. lat. $=2^{\circ} .5 \mathrm{~N}$, long. $=115^{\circ} .5 \mathrm{~W}$

area took place and consequently thermo-remanent magnetization of those rocks was produced, the direction of magnetic polarization of each specimen is transformed to that referred to the assumed ancient co-ordinates of the horizon and the meridian. The direction thus transformed of each specimen is shown also in Table 1.

The average position of the North pole of the earth's dipole corresponding to the transformed magnetic polarization is given as :

$$
\text { lat. }=3^{\circ} \mathrm{N} \text {. and long. }=107^{\circ} \mathrm{W} .
$$

where the radius of circle of confidence of 5 per cent is $7^{\circ}$.

It may be concluded from this result that the North pole of the Earth's magnetic dipole was situated approximately at $107^{\circ} \mathrm{W}$. in longitude near the equator in the Pre-Cambrian, assuming that there has been no remarkable drift and rotation of the antarctic continent. In the southern hemisphere, palæomagnetic studies on Pre-Cambrian rocks in Australia ${ }^{3}$ and South Africa ${ }^{4}$ have already been carried out. For comparison, the results of these Australian and South African data are shown in Table 2 together with the present one.

Comparing these results to each other, it will be seen that the pole position derived from the present data is in rather good agreement with that derived from the South African data, while the Australian data, especially the last two results in Table 2, are appreciably different from the upper two. It might be suggested that the rough agreement between the present and the South African results can be attributed to the condition that these two localities are situated at nearly the same longitude though they are separated from each other by about $35^{\circ}$ in latitude.

TABLE 2

\begin{tabular}{cccc} 
Locality & \multicolumn{1}{c}{ Author } & \multicolumn{2}{c}{ Pole Position } \\
& & Lat. & Long. \\
Antarctic & Nagata \& Shimizu & $3^{\circ} \mathrm{N}$. & $107^{\circ} \mathrm{W}$. \\
South A frica & Gough (ref. 3) & $8^{\circ} \mathrm{S}$. & $137^{\circ} \mathrm{W}$ \\
Australia & Irving \& Green (ref. 3) & $30^{\circ} \mathrm{N}$. & $121^{\circ} \mathrm{W}$. \\
& & $51^{\circ} \mathrm{N}$. & $18^{\circ} \mathrm{W}$. \\
& & $6^{\circ} \mathrm{N}$. & $14^{\circ} \mathrm{W}$.
\end{tabular}

As for the Pre-Cambrian pole position, a number of data have also been reported with respect to European and American rocks in the northern hemisphere. Although these northern hemisphere data $^{5}$ do not give an unique pole position of the earth's dipole, it may be said that most of those pole positions are situated between the equator and $35^{\circ} \mathrm{N}$.

Summarizing all data obtained hitherto, including the present antarctic one, it may be substantially said that the pole-position of the earth's dipole, estimated by the palæomagnetic mothod, was situated near the equator in the Pre-Cambrian Period.

\section{T. Nagata}

Geophysical Institute,

University of Tokyo.

$$
\text { Aug. } 27 .
$$

'Nagata, T., 'Special Report on Palæomagnetism', Trans. Rome Meeting A.G.A., I.U.G.G., 343.

2 Yoshikawa, T., and Toya, H., Antarctic Report, No. 1, 1 (1957) Tatsumi, T., and Kikuchi, T., Antarctic Report, No. 7 (1959) (in

the press).
${ }^{3}$ Gough, D. I., Mon. Not. Roy. Astro. Soc, Geophys. Suppl., 7, 196 (1956).

Irving, E., and Green, R., Geophys. J. Roy. Astro. Soe., 1, 64 (1958).

"See, for example, a summary by Irving, E., Geophys. J. Roy. Astro. Soc., 2, $51(1959)$.

\section{GEOLOGY}

\section{The Geological Time-Scale}

Since my communication on this subject was written $^{1}$, much has happened. Prof. J. L. Kulp ${ }^{2}$ has just published a time-scale in which the duration of the geological periods is given as follows : Ordovician, 490-430 m.y.; Silurian 430-410 m.y.; Devonian 410-355 m.y.; Mississippian 355-330 m.y.; Pennsylvanian 330-275 m.y.; Permian 275-220 m.y.; Triassic 220-180 m.y.; Jurassic 180-135 m.y.; Cretaceous 135-70 m.y. An almost identical geochronology ( $\pm 5-10 \mathrm{~m} . \mathrm{y}$.$) , awaiting publication, was$ communicated to me privately by Prof. A. Holmes ${ }^{3}$ a month ago. The Oxford age of $305 \mathrm{~m} . \mathrm{y}$. for Dartmoor granite (by potassium/argon assay on biotite) has been confirmed by Dr. H. Faul ${ }^{4}$ of U.S. Geological Survey $(292 \mathrm{~m} . \mathrm{y}$. and $288 \mathrm{~m} . \mathrm{y}$. on the same rock by the same method). A full isotopic assay of Hercynian pitchblende from Geevor, Cornwall, has yielded to Dr. A. G. Darnley ${ }^{5}$ of the Geological Survey of Great Britain a comparable date of $288 \mathrm{~m} . \mathrm{y}$. From all this it is confirmed that an extension of the Holmes $B$ time-scale is called for, and that the best values are, as one would expect, a little higher than the averages of the experimental results published previously ${ }^{1}$. There is however, no support from recent researches for the conclusion that the Lower Cambrian is older than $600 \mathrm{m.y}$.

Department of Geology,

University of St. Andrews,

$$
\text { C. F. Davidson }
$$

Scotland.

Nov. 4.

\footnotetext{
1 Nature, 184, 1310 (Oct. 24, 1959).
2 Kulp, J. L., Program 1959 Annual Meeting, Geol. Soc. America. (Nov. 2, 1959).

3 Holmes, A. (personal communication, Oct. 6, 1959).

5 Darnley, A. G., Geol. Surv. Great Britain, Age Determination Rep., 6
} 